\title{
The discursive construction of digitalization: a comparative analysis of national discourses on the digital future of work $^{\dagger}$
}

\author{
Matteo Marenco ${ }^{1}\left(\right.$ iD and Timo Seidl ${ }^{2, *}$ (i) \\ ${ }^{1}$ Faculty of Political and Social Sciences, Scuola Normale Superiore, Florence, Italy and ${ }^{2}$ Centre for European Integration \\ Research, University of Vienna, Vienna, Austria \\ ${ }^{\star}$ E-mail: timo.seidl@univie.ac.at
}

(Received 13 November 2020; revised 08 April 2021; accepted 10 April 2021; first published online 07 June 2021)

\begin{abstract}
New forms of work intermediation - the gig economy - and the growing use of advanced digital technologies - the new knowledge economy - are changing the nature of work. The digitalization of work, however, is shaped by how countries respond to it. But how countries respond to digitalization, we argue, depends on how digitalization is perceived in the first place. Using text-as-data methods on a novel corpus of translated newspaper and policy documents from eight European countries as well as qualitative evidence from interviews and secondary sources, we show that there are clear country effects in how digitalization is framed and fought over. Drawing on discursive-institutionalist and coalitional approaches, we argue that institutional differences explain these discursive differences by structuring interpretative struggles in favor of the social coalitions that support them. Actors, however, can also challenge these institutions by using the discursive agency to change these underlying support coalitions.
\end{abstract}

Keywords: digitalization; future of work; discursive institutionalism; text as data

\section{Introduction}

From manufacturing goods to building relationships, from daily business to everyday life, from credit scores to social scores: digital technologies are rapidly transforming the way we live our lives and run our economies. But digitalization is no force of nature. It does not just sweep over the world, leveling everything in its path. Rather, it is molded and channeled by the uneven landscape of history and politics. Take the ride-hailing platform Uber as an example.

Uber has aggressively rolled out its app in dozens of countries, probing the bounds of existing labor and taxi regulations. Different countries, however, have 'responded in wildly different ways to [Uber] - from welcome embrace and accommodating regulatory adjustments to outright rejection and legal bans' (Thelen, 2018, p. 938). And not only that. The advent of Uber also provoked very different discursive 'flashpoints' (Thelen, 2018, p. 939) around which political struggles later revolved (e.g. taxation, competition, employment rights). These flashpoints, while resulting from institutional differences (e.g. different welfare systems), shaped the terms of public discourse on Uber. They led to the mobilization of different actors and the formation of different coalitions

\footnotetext{
${ }^{\dagger}$ We would like to thank Dorothee Bohle, Guglielmo Meardi, and the participants of the ECPR panel on the Politics, Governance, and Regulation of Big Transformations for their helpful comments on earlier versions of this paper. We would also like to thank the three anonymous reviewers for exceptionally constructive feedback. 
(e.g. taxpayers and regulators vs. Uber, Uber and consumers vs. drivers), which help explain the different regulatory responses.

This teaches us two lessons: first, platform companies like Uber are not only regulated differently; they are also talked and thought about differently (e.g. as a taxation vs. a labor law problem). Second, to understand political responses to digitalization, we need to understand how institutions influence the terms on which political struggles are fought. For country-specific characteristics 'do not simply channel the same conflict in distinctive ways', but often 'translate seemingly common trends into wholly different problems in divergent national contexts' (Thelen, 2018, p. 939).

An institutional theory of digitalization, therefore, not only needs to account for 'diverse responses to common challenges' (Steinmo and Thelen, 1992, 6), but also for how seemingly common challenges are 'refracted into divergent struggles over particular national practices' (Locke and Thelen, 1995, p. 338). This refraction, we contend, happens in discourse, that is the process through which agents articulate and communicate the substantive content of ideas (Schmidt, 2008). It is in discourse where actors voice their concerns about digitalization and express what they think are its defining features and central challenges (Kjær and Pedersen, 2001; Schmidt, 2008; Wueest, 2013). And, it is in discourse that global trends are translated into local problems - problems that subsequently influence the scope and nature of political solutions (Hay and Rosamond, 2002).

To be clear, our argument is not that discourse is all that matters. On the contrary, discourse itself is shaped by the politico-economic status quo and the social coalitions that underpin it. But digitalization also provides actors with an opportunity to build new coalitions and challenge this status quo (Emmenegger, 2021). In this article, we put forward a discursive-institutionalist analysis of the varying ways in which digitalization is framed and fought about in eight European countries. We use various text-as-data approaches (Grimmer and Stewart, 2013) on a novel dataset of text corpora to show how actors talk about digitalization (sentiment analysis) and what they talk about (keyword extraction, topic modeling). In addition, we use more qualitative evidence from interviews and fieldwork, as well as secondary sources to contextualize these findings and show how discursive agency manifests itself. Our datasets consist of two types of corpora: articles in quality newspapers to analyze 'communicative discourse' between political actors and the public; and policy documents such as government white papers or manifestos by trade unions and business groups to analyze 'coordinative discourses' among policy actors (Schmidt, 2008).

While digitalization is a multifaceted process, we limit our analysis to one of its most important dimensions: the digital transformation of work (Neufeind, O’Reilly and Ranft, 2018). This refers to both the emergence of new forms of both online and offline work intermediation through digital platforms ('gig economy') (de Stefano, 2016; Prassl, 2018); and the growing use of advanced digital technologies like artificial intelligence to further rationalize the production process ('new knowledge economy') (Brynjolfsson and McAfee, 2014; Schwab, 2016). The former poses the problem of how to adapt labor regulations and social security systems to novel - and often highly precarious forms of work; the latter raises the question of how to prepare workers for - and compensate them in - a world in which machines can perform more and more tasks.

Our results suggest that digitalization is indeed talked and thought about in very different ways in different countries, and that these differences reflect underlying politico-economic differences (Wueest, 2013). In particular, we show that while socioeconomic factors matter, institutions are the primary source of national differences, or 'country effects' (Lloyd and Payne, 2019) in how digitalization is discussed. Based on our findings, we develop a typology of digitalization discourses that captures how collaborative (vs. conflictual) as well as how opportunity-focused (vs. threat-focused) national discourses are. In addition, we show that while institutions shape how actors perceive novel phenomena, actors can also use their discursive agency to challenge or reinvent these institutions. 
Our paper makes three contributions. First, we provide a comprehensive mapping of digitalization discourses in a diverse set of eight European countries, showing that digitalization is far from being the same problem everywhere. Second, we theorize and empirically demonstrate how institutions - and their underlying support coalitions - mediate the digital transformation of societies and economies by shaping how digitalization is framed and fought over. Third, we show how novel text-as-data methods can be used to answer discursive-institutionalist questions, even and perhaps especially when they are comparative in nature.

We proceed as follows. We will first present our research questions and elaborate on our argument. We then outline our theoretical framework. Next, we explain our dataset and methodological approach, and discuss our empirical results. We conclude with a brief summary of our results and a discussion of the contributions and shortcomings of our paper.

\section{Research questions and argument}

Technological change is often portrayed as an unstoppable, tsunami-like force that simply rushes over societies. Economic history, however, is full of examples of 'successful' resistance to or differential adaption of new technologies (Frey, 2019). In fact, whether new technologies are outrightly banned or eagerly introduced - or anything in between - 'depends on who stands to gain from them and the societal distribution of political power'. Technological change, in other words, is a profoundly political and politically contested process whose outcome depends not just on the technologies themselves, but on how countries react to them. And these reactions can differ quite dramatically.

But how to explain this variation? While much work on digitalization is rather devoid of a comparative perspective, an emerging 'varieties-of-digitalization' literature has started to pay attention to 'country effects' in the way that digitalization is viewed and responded to (Lloyd and Payne, 2019; Thelen, 2018). In this paper, we build on this literature - as well as existing country case studies - to draw attention to three things: first, to the systematic differences in the way that digitalization is thought and talked about in different countries; second, to the importance of institutions in structuring the way digitalization is understood; and third, the limited although important role of discursive agency in challenging and changing existing institutions. We address three research questions. First, are there relevant and theoretically meaningful differences in the way countries talk about digitalization? Finding descriptive differences in discursive tone or content is the minimal condition for a discursive-institutionalist account of country effects. Put differently, mapping discursive diversity is a precondition for explaining it.

Second, to the extent that there are such 'country effects', how do we explain them? Why do countries perceive digitalization differently, and what is the relative importance of socioeconomic versus institutional factors?

Third, to what extent do different discourses merely reflect politico-economic differences economic or institutional - and to what extent do they leave room for the discursive agency? In other words, is discourse mainly a locus of continuity where structurally or institutionally powerful actors express their interests? Or is it a locus of change in which actors can challenge existing ways of thinking about and doing things? The example of Uber has shown that different discursive flashpoints organize debates around platform work and thus shape the coalitions in favor of specific regulatory responses (Thelen, 2018). But do these discursive flashpoints merely reflect underlying institutional differences, or is there room for a genuine discursive agency?

Our discursive-institutionalist conjecture is that discourses on digitalization (i) differ systematically across countries (the descriptive part) because (ii) institutional differences give different meaning and relevance to it (the institutional part); and( iii) because actors can use discourse to build new coalitions or drive a wedge between existing ones, thereby challenging and changing existing institutions (the agency part). 
This addresses the two sides of the structure-agency debate in institutional theory. On the one hand, institutions are said to structure the ways in which novel problems are perceived, conceived, and ultimately assimilated. On the other hand, such accounts are criticized for being overly deterministic and for downplaying the opportunities that novel problems present to actors that are interested in changing (or shoring up) institutional arrangements. These two sides, however, are not incompatible. As the next section fleshes out, they can be reconciled by understanding (discursive) agency as the 'coalitional work' that goes into creating, maintaining, and changing institutions, while acknowledging the difficulties involved in challenging an institution's underlying support coalition (Capoccia, 2016; Emmenegger, 2021; Hall, 2016). Discourse matters because it offers a window into the operation of both institutional structure and agency: it is in discourse that cultural categories are institutionalized and novel problems assimilated to existing ways of thinking (Capoccia, 2016, p. 1104). But, it is also in discourse that actors contest the meaning and legitimacy of an institution (Schmidt, 2010, p. 15). A discursive-institutionalist analysis thus allows for more 'rounded accounts of agency within institutional settings' (Bell, 2012, p. 718) - accounts that take seriously both the 'partial bite' of institutions (Capoccia, 2016) and the possibility of discretionary spaces.

\section{Theoretical framework}

Institutionalism evolved as a research program focusing on how institutions structure actors' behavior, thus explaining 'policy continuities over time within countries and policy variation across countries' (Steinmo and Thelen, 1992, 10). More recently, institutionalists have turned their attention to the role of actors in changing institutions by exploiting the inevitable incompleteness and ambiguity of institutions (Streeck and Thelen, 2005, p. 14). What an institution 'really means' is never quite clear but is negotiated in a continuous 'interpretative struggle' over its meaning, scope, and legitimacy (Streeck and Thelen, 2005, pp. 14-15). Actors can thus, in principle, challenge and change the institutions in and under which they operate.

This growing focus on agency, however, raises the 'paradox of plasticity' (Hall, 2016, p. 39): if the agency and institutional change are ubiquitous, what remains of the very stickiness and 'patterning' effects that inspired institutionalist analysis in the first place? The 'coalitional turn' (Emmenegger, 2021, p. 2) in the institutional analysis is meant to address this problem (Hall and Thelen, 2009). It conceptualizes institutions 'as the product of social coalitions' (Hall, 2016, p. 39) and agency in terms of 'the creation and maintenance of social coalitions that stabilize or challenge institutions' (Emmenegger, 2021, p. 2). The advantage of such a coalitional understanding of institutions is that it allows to 'strike a middle ground between characterizing institutions as absolutely constraining or as malleable tools in the hands of powerful actors' (Capoccia, 2016, p. 1100). While institutions are 'creatures of coalitions' (Hall, 2016, p. 42) and therefore rely on the continuing support of actors, they also sustain the coalitions that support them (Hall, 2016) - for example, by providing incumbent coalitions with material benefits (Pierson, 2000) or control over the timing of institutional reform (Capoccia, 2016). ${ }^{1}$

Another way in which institutions 'bite' - and the one on which we focus here - is through the 'institutionalization of cultural categories' (Capoccia, 2016, pp. 1102-1107). Institutions not only play a regulative role. They also play a constitutive role (Emmenegger, 2021, p. 7) by shaping how 'different groups come to have particular beliefs and conceptions of the world, their roles in it and their interests' (Whitley, 2007, p. 549). 'Interpretative feedback effects' (Capoccia, 2016, p. 1102) tilt the interpretative struggles over institutions in favor of their support coalitions. Reformers, meanwhile, need to do a lot of 'definitional work' to change established categories and ways of thinking (Capoccia, 2016, p. 1106). Novel problems are therefore often viewed in light of

\footnotetext{
${ }^{1}$ At the same time, collective action problems make it difficult for challenger coalitions to unseat incumbent coalitions (Emmenegger, 2021).
} 
existing national models and, as a result, problem definitions and policy solutions follow ideational path dependencies (Cox, 2004; Kjær and Pedersen, 2001).

Discursive institutionalists have theorized this constitutive effect of institutions through the concept of background ideational abilities, which allow actors to create and maintain institutions (Schmidt, 2008, p. 314). But they have also argued that institutions are not as 'sticky' and actors not as 'unthinking' as they are often made out to be. This is because actors also have foreground ideational abilities, which they can use 'to think, speak, and act outside their institutions even as they are inside them, to deliberate about institutional rules even as they use them, and to persuade one another to change those institutions or to maintain them' (Schmidt, 2008, p. 314).

Conceptualizing actors as endowed with both background and foreground ideational abilities addresses another paradox of institutionalist theory: the 'paradox of embedded agency'; it explains how actors, 'whose belief and actions are strongly shaped by existing institutions [can] break with these very same institutions and innovate' (Emmenegger, 2021, p. 6). Together, coalitional and discursive-institutionalist perspectives allow us to understand two things at the same time: (i) how the common trend of workplace digitalization is not in fact 'translated into common pressures in all national economies' but - through the constitutive power of institutions - 'refracted into divergent struggles over particular national practices' (Locke and Thelen, 1995, p. 338) and (ii) how actors can use their discursive agency over digitalization to challenge coalitions, build new ones, and thereby change these national practices.

On the one hand, actors frame novel problems in ways that make defection from existing institutions less likely. For example, they stress certain aspects (e.g. taxation) of digitalization more than others (e.g. employment status), thereby rallying the supporters of a tax-based welfare system behind certain types of regulations (Thelen, 2018). ${ }^{2}$ By asserting the continuing relevance and legitimacy of established ways of doing and thinking about things, these frames shore up the coalitions that support the institutional status quo (Capoccia, 2016, p. 1105). On the other hand, actors can frame a novel problem as an opportunity for change - or as necessitating it. By pointing to the inadequacy of the institutional status quo, these frames can be used to build new coalitions or drive a wedge between existing ones.

In sum, by taking seriously the coalitional underpinnings of institutions as well as the effect of (institutional) context on actors' background ideational abilities and the possibility of agency that exists because of actors' foreground ideational abilities, this approach strikes 'a middle ground between characterizing institutions as absolutely constraining or as malleable tools in the hands of powerful actors' (Capoccia, 2016, p. 1100). Institutions are created, maintained, and challenged by social coalitions, and a key part of their coalitional work is the definitional work of framing novel problems in ways that either reassert existing practices - or break with them.

\section{Empirical strategy and data}

Testing the twin arguments of institutional structuring and discursive agency requires combining two empirical strategies. First, we need ways to systematically assesses whether and how discourses on digitalization differ across countries. Second, we need ways to connect these findings to the actual political strategies of social actors - their efforts in defending and defecting from existing institutions, and in keeping together or breaking apart the coalitions that sustain these institutions. The first task is accomplished using methods of quantitative text analysis; the second one through triangulating these findings with case studies based on fieldwork and secondary sources.

For the quantitative text analysis, we compiled two novel text corpora for eight European countries: France, Germany, Ireland, Italy, Poland, Spain, Sweden, and the UK. The rationale for our case selection was to investigate discursive diversity among countries that share some basic

\footnotetext{
${ }^{2}$ Following Entman (1993, p. 53), we understand framing as 'selecting and highlighting some features of reality while omitting others' and discourse, following Schmidt (2010), as the interactive exchange of such frames.
} 
commonalities. Each of our eight countries, with the partial exception of Poland, is an advanced capitalist democracy, and each was, for the period under study, a medium-sized to large member of the European Union. Despite these similarities, the countries under study also differ in important respects, both with regard to the structure of their economy and with regard to their institutional makeup. This constrained diversity provides us with the appropriate setting to study how structural and institutional diversity is reflected in discourse.

The first corpus we collected consists of 6235 newspaper articles that directly relate to the digitalization of work and were published between 2013 and 2019. Articles were collected from major national newspapers, either directly or via Factiva. We prioritized quality over quantity (cf. Nicholls and Culpepper, 2020), selecting only articles that contained an explicit reference to the gig economy, workplace automation and robotization (including artificial intelligence), or the Fourth Industrial Revolution or Industry 4.0 in their headline or lead paragraph (for details, see online Appendix A.1). This corpus represents what Schmidt (2008) calls the communicative discourse between policymakers and the public and is broadly reflective of the overall public discourse on digitalization in a country.

The second corpus consists of 2337 (sometimes split) documents published between 2012 and 2019 by major social partners, namely unions, governments or ministries, and employer organizations. Following this actor-based logic, documents were collected from the web, based on relevant search strings and available lists of the main stakeholders in each country (e.g. the national member organizations of the European Trade Union Confederation). Longer documents (over 40,000 characters) were split chapter-wise or similarly to have more and more meaningful units of analysis (for details, see online Appendix A.2). This second corpus represents what Schmidt (2008) calls the coordinative discourse among policymakers and is broadly reflective of the elite discourse on digitalization.

Substantively, both corpora cover the digitalization of work, which we understand as a twopronged process. The first prong refers to new platform business models that enable and control novel interactions between buyers and sellers of labor; the second prong refers to the ways in which digital general-purpose technologies increasingly affect the ways in which businesses organize production in both the service and the industrial sector ('Industry 4.0'). We thus distinguish between new forms of online and offline work intermediation through digital platforms - what is often referred to as the 'gig economy' (de Stefano, 2016; Prassl, 2018); and the growing use of advanced digital technologies that promise to transform the production process more generally - what is variously referred to as the second machine age, the Fourth Industrial Revolution, or the (new) knowledge economy (Brynjolfsson and McAfee, 2014; Schwab, 2016).

These two dimensions of digitalization come with different challenges. The former intensifies existing trends of workplace casualization (de Stefano, 2016). It poses the problem of how to adapt labor regulations and social security systems to minimize the costs while maximizing the benefits of new, digitally intermediated forms of work. The latter intensifies existing trends of industrial and service-sector automation and routine-biased technological change (Frey, 2019). This raises the question of how to make sure that workers have the necessary skills to remain in the labor market or are provided with alternative sources of income.

Both corpora were automatically translated into English, using Google's Translate API. Other studies have shown that this works as well as gold-standard translations for both dictionary-based and unsupervised methods of text analysis (Proksch et al., 2019; Vries, Schoonvelde and Schumacher, 2018). Building on these studies, we use the translated corpora as input for various methods of automated text analysis. ${ }^{3}$ While these methods inflict a certain degree of 'semantic violence' on texts, they can also be extremely useful when carefully validated and interpreted,

\footnotetext{
${ }^{3}$ For translation, preprocessing, NLP annotation, and the analyses, we mainly relied on the R packages googleLanguageR (Edmondson, 2020), quanteda (Benoit et al., 2018), spacyr (Benoit and Matsuo, 2020), stm (Roberts, Stewart and Tingley, 2018), and UDPipe (Wijffels, 2019) as well as the tidyverse packages (Wickham et al., 2019).
} 
Table 1. Interview Table

\begin{tabular}{|c|c|c|c|c|c|}
\hline Country & Interview Code & Interview Category & Interviewee Role & Interview Date & Place of Interview \\
\hline FR & GOV $_{1}$ & Policymaker & National Digital Council & 28.02 .2020 & Paris \\
\hline FR & $\mathrm{PA}_{1}$ & Platform activist & President and Coordinator Active member, Collective Autonone de Livreurs de Paris (CLAP) & 21.02 .2020 & Paris \\
\hline FR & EXP1 & Expert & Labour Sociologist (Université Paris Dauphine-PSL) & 11.02 .2020 & Paris \\
\hline FR & $\mathrm{EXP}_{2} / \mathrm{TU}_{1}$ & Expert/Trade Unionist & Economist, Insitut de Recherches Economiques et Sociales (IRES) & 17.02 .2020 & Paris \\
\hline IT & EXP1 & Expert & Labour lawyer, IE Law School & 31.03 .2020 & Online \\
\hline ESP & EXP1 & Expert & Labour sociologist, Malaga University & 10.04.2020 & Written Interview \\
\hline $\mathrm{DE}$ & $\mathrm{GOV}_{1}$ & Policymaker & Affiliate of a Federal German Ministry & 01.10 .2019 & Berlin \\
\hline
\end{tabular}

which we discuss below (Benoit, 2020). In addition, it is crucial to align theory and method. In this paper, we assume that the frequency of certain words is substantively meaningful (e.g. because it tells us something about dominant framings), so we can use bag-of-words approaches like topic models (cf. Nicholls and Culpepper, 2020). If, however, we assumed words derive their meaning from 'the company they keep' and are interested in how their meaning changes over time or across contexts, word embeddings would be a more fitting approach.

In this paper, we use three text-as-data methods that match our theoretical interest in the tone and content of discourse. First, we are interested in how digitalization is talked about in a given country. For that purpose, we use sentiment analysis to identify the relative number of positive versus negative terms in different documents. We use the Lexicoder Sentiment Dictionary, which was specifically designed for political text (Young and Soroka, 2012), taking into account negators (positive negatives and negative positives) as well. We cross-validate this approach by using four additional dictionaries (for details, see online Appendix B.1).

Second, we are interested in what is said in a given country. To investigate this, we use various keyword extraction techniques as well as structural topic modeling. ${ }^{4}$ Keyword extraction techniques make it possible to identify words or n-grams that capture essential content. We use four of such techniques: the RAKE algorithm, the TextRank algorithm and sentence-based, as well as SkipGram-based co-occurrence metrics (for details, see online Appendix B.2).

Topic modeling allows us to identify common themes in our corpus. Topics are modeled as probability distributions over words and documents as probability distributions over topics (Blei, 2012). Put differently, topics are understood as combinations of words (or n-grams) and documents as mixtures of topics. Structural topic modeling extends this basic topic model by allowing observed covariates to influence the proportion of a document devoted to a topic (the topic prevalence). This allows us to estimate the conditional expectation of a topic occurring, given that a document is from a certain country or part of the communicative discourse. We chose a topic model with $\mathrm{k}=60$ topics, some of which we subsequently combined into 'frame packages' (Nicholls and Culpepper, 2020, p. 11). Online Appendix B.4 provides a detailed discussion of our choice of $\mathrm{k}$, preprocessing steps, interpretation, and validation, as well as a complete list of topics with terms, labels, and assigned frame package.

We rely on qualitative evidence to complement our quantitative findings. In particular, we relied on in-depth analysis of relevant governments' and social partners' policy documents, academic as well as journalistic sources. For four countries in our sample - France, Spain, Italy, and Germany - we complemented this document analysis with semi-structured interviews with members of employment ministries, social partners concerned with the digitalization of work, as well as platform activists and experts (see Table 1). Where we did not collect interview data, we rely on the aforementioned secondary literature only. The purpose of such qualitative data are twofold: first, to let the quantitative discourse analysis 'come to life', that is, to show how discursive differences relate to what actually happens 'on the ground'; and second, to zero

${ }^{4} \mathrm{We}$ also use a version of word vectors. For details and results, see online Appendix B.3. 


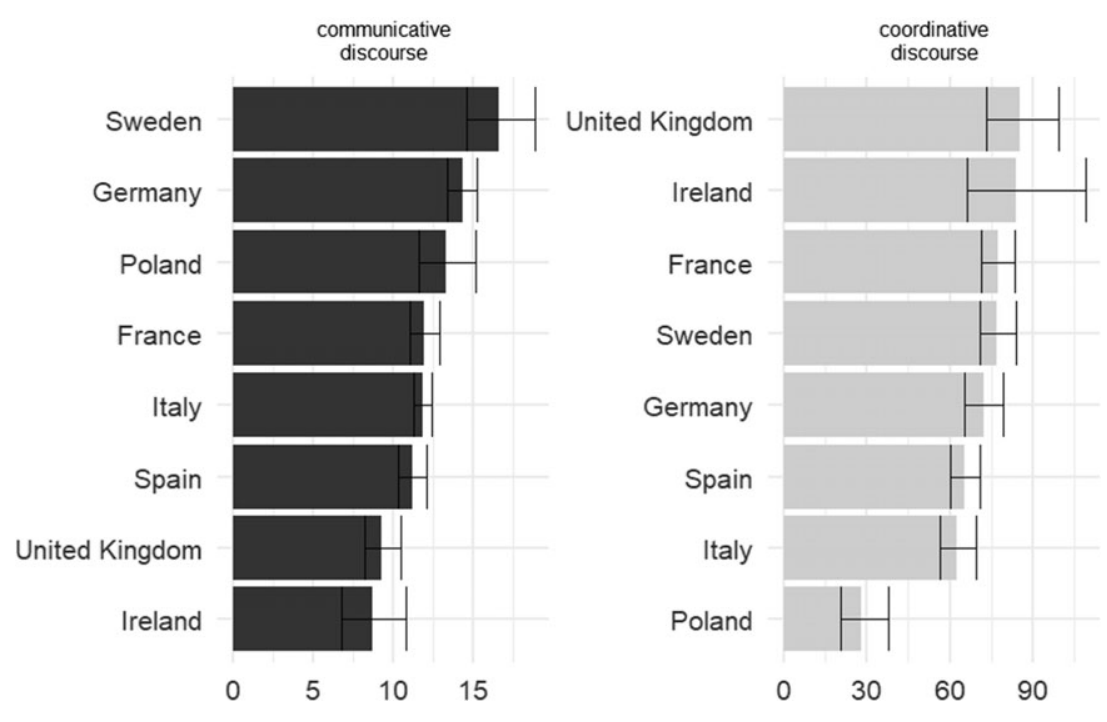

Figure 1. Discursive sentiment across countries and discourse types with $95 \%$ bootstrapped confidence intervals ( $R=$ 10000).

in on the relative importance of institutional structure and discursive agency, which we can only superficially analyze quantitatively.

\section{Results and discussion}

Do discourses on the digital future of work differ in tone and content across countries, and if so, how do we explain these differences? Here, we first look at the tone of discourse and tentatively derive a typology of digitalization discourses. We then flesh out this typology by looking at the content of discourse. In both cases, as highlighted above, we combine quantitative evidence - from the sentiment analysis in the case of discursive tone and from keyword extraction methods and topic models in the case of content - with qualitative data from secondary sources and interviews.

\section{The tone of discourse}

The relative number of positive versus negative words is a good proxy for a country's view of digitalization: is it perceived as something bad, threatening, destructive? Or as something good, promising, useful? Figure 1 plots discursive sentiment across different countries, for different dictionaries, as well as separately for coordinative and communicative discourses (with values averaged across dictionaries). ${ }^{5}$ The first finding is that Sweden has by far the most positive discourse. Importantly, this cannot be explained by the country's economic position alone. The UK or Ireland also has service-dominated economies with many companies close to the digital frontier. But they perceive digitalization more negatively. We argue that what explains these differences is not the structure of Sweden's economy but the nature of its institutions.

Specifically, Sweden has an institutionalized tradition of proactively and inclusively adapting to technological change. This makes digitalization a lot less scary (Katzenstein, 1985). Sweden's embracing view of digitalization is epitomized by the opening quote of a recent report by its digitalization commission: Tempora mutantur nos et mutamur in illis - the times change, and

\footnotetext{
${ }^{5}$ In the appendix, we provide wordclouds with the most commonly matched positive and negative words to illustrate what a positive or negative tone means and to further validate this approach. We thank an anonymous reviewer for this suggestion.
} 
we change with them. 'In Sweden', as the Swedish Minister for Employment and Integration, Ylva Johansson, put it, 'if you ask a union leader, 'Are you afraid of new technology?' they will answer, 'No, I'm afraid of old technology. ( . . . ) The jobs disappear, and then we train people for new jobs. We won't protect jobs. But we will protect workers" (Goodman, 2017). Institutionally, this is reflected, among other things, in the country's job security councils, which are jointly run by employers and trade unions and which give intensive support and retraining to people when they are laid off. As we will further see below, Sweden's ability to collaboratively negotiate technological change, fundamentally changes the country's view of and reaction to digitalization. By contrast, Poland stands out by having a particularly negative coordinative discourse, precisely because it lacks an established tradition of social and policy dialogue. As a result of this difficulty of building cross-class coalitions, there is a conspicuous lack of forward-looking plans and institutionalized cooperation in shaping digital change.

The UK and Ireland also lack such a system of institutionalized cooperation between winners and losers of technological change. This results in a particularly negative communicative discourse and a government-dominated coordinative discourse, which pushes unions into voicing their concerns directly to a receptive public. The Irish government, for example, is very sanguine about digitalization, having long espoused an active policy of catering to tech companies and casting Ireland as a digital frontrunner (Brazys and Regan, 2017). By contrast, the Irish public appears more worried about digitalization's potential downsides and inequities, as evidenced by the much more negative discourse on the digital future of work. Our findings dovetail with a recent study, which finds that at least $25 \%$ of the Irish population finds itself excluded from an increasingly digital society because of socioeconomic reasons, and almost half describe themselves as lacking digital skills (Accenture, 2020). Similarly, the British government frames digitalization very positively, but its unilateral celebration of digitalization as a vindication of and boost to the British way does not chime well with a more skeptical public.

There are large class and regional disparities in Britain when it comes to digitalization, and less trust in the country's ability to find collaborative solutions. Unions, for example, are irritated by the government's unilateral approach, which did not involve them in drafting the UK's digital industrial strategy, and which one-sidedly stressed the benefits of the flexible 'British way' in its response to the Taylor Review of Modern Working Practices (UK Government, 2018a). This response struck many as rather tone-deaf at a time when digitalization threatened to exacerbate the downsides of the flexible British labor market. Again, it is institutions - in this case, a lightly regulated labor market and a unilateral (as opposed to corporatist) style of policymaking that result in large discrepancies between a relatively cheerful discourse by the government and a much more negative discourse among the public.

Importantly, without having a seat on the table and without being listened to, unions resort to more dramatizing discursive strategies. They also shift their focus from the coordinative to the communicative discourse and address the public more directly, which explains the quite positive coordinative and the quite negative communicative discourse (cf. Schmidt, 2008, pp. 312-313). . Using an aggressive style of campaigning that highlighted the conflicts and inequities in the British labor market, the Independent Workers Union of Great Britain (IWGB), for example, successfully raised awareness for the working conditions not just of gig workers but of precarious workers in general. As the IWGB's Vice President Mags Dewhurst puts it, 'this isn't just about the gig economy. All business is going more and more digital, leaner and leaner. ( . . ) Next, it will be banking and retail. These bad practices have to be stopped now' (Roberts, 2018). Thus, the IWGB has used the spotlight that digital platforms have put on the inequities of the British labor market to challenge the support coalition behind the flexible 'British way', for example by pointing to the widespread nonenforcement of labor rights, which is not limited to platform companies (Roberts, 2018).

${ }^{6} \mathrm{We}$ thank an anonymous reviewer for drawing our attention to this discursive venue shopping. 
Table 2. Typology of digitalization discourses

\begin{tabular}{lll|l|} 
& \multicolumn{2}{c}{ Policymaking Style } \\
\cline { 2 - 3 } Digitalization Perception & Collaborative & Conflictual \\
\cline { 2 - 3 } & Opportunity & Proactive Discourse & Unilateral Discourse \\
\cline { 2 - 3 } & Threat & Compensatory Discourse $\mid$ Luddite Discourse \\
\cline { 2 - 3 }
\end{tabular}

In sum, the tone of public discourse clearly differs across countries. As the above discussion has hinted at and as the analysis of discursive content will flesh out, discourses differ along two dimensions. The first dimension relates to how collaborative policymaking is. Specifically, corporatist countries seem to be better at mitigating fears of technological disruption. This is because the losers of technological change can plausibly assume that they will either be compensated in the digital future or prepared for what it brings, allowing for broader coalitions in favor of technologyembracing policies (Katzenstein, 1985; Ornston, 2012). The stakes are higher in countries with a more conflictual style of policymaking, where each side has to fear that the other gets its way and one ends up getting the short end of the stick, which inclines groups to fight for their short-term interests. The second dimension has to do with whether previous experiences with technological change and a country's politico-economic makeup incline countries to perceive digitalization as an opportunity or as a threat. Is my country likely to benefit from digitalization, can it be an opportunity to overcome existing problems or will it make them worse? While the first dimension reflects purely institutional differences, the second dimension has both economic and institutional elements (e.g. the distance to the digital frontier, the nature of the labor market).

Table 2 brings these two dimensions together, distinguishing between four ideal-typical discourses. If the policymaking style is collaborative and digitalization is viewed as an opportunity, a proactive discourse dominates in which digitalization is embraced and the emphasis is on investments that help workers and companies survive and thrive in a digital economy. This makes it much easier to build broad coalitions that support future-oriented institutions such as (re-)training programs. If the policymaking style is at least somewhat collaborative but digitalization is viewed as a threat, the focus is on how to passively compensate individuals and businesses that stand to lose from digitalization. If the policymaking style is conflictual and digitalization is viewed as an opportunity, the discourse will be unilateral in the sense of different actors emphasizing their own and often conflicting interpretations of how digitalization can benefit society. If the policymaking style is conflictual and digitalization is viewed as a threat, a Luddite discourse will emerge in which actors try to stop or reverse digitalization to the extent that it hurts them. This will lead to narrow, conflicting coalitions, which makes it hard to build future-oriented institutions. The following paragraphs will add empirical flesh to these conceptual bones by zeroing in on the content of discourse, and by showing how actors can use their discursive agency to either confirm the discursive status quo or shift discourses from one quadrant to another.

\section{The content of discourse}

Not only do digitalization discourses differ in tone, they also importantly diverge in content. Figures 2 depicts the most important keywords identified by three keyword extraction algorithms. ${ }^{7}$ It depicts - with size indicating importance - the unigrams and bigrams that we can think of as most 'essential' to the communicative (black) and coordinative (gray) discourses in the respective countries. They capture the issues around which national discourses revolve. Figure 3 depicts the estimated effect of the country covariate on the prevalence of different topics

${ }^{7}$ For details on these methods, and for similar results using the TextRank algorithm, see online Appendix B.2. 
(a)

France

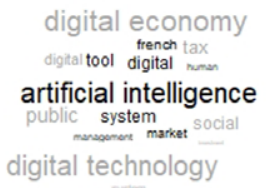

Poland

labor market Artificial intelligence labor market artificial intelligence taxi drivers taxi driver syste digital competence artificial intelligence polish economy

(b) France

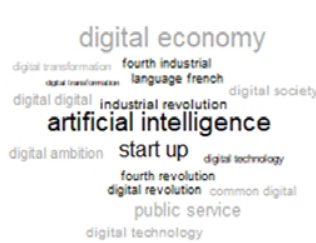

Poland

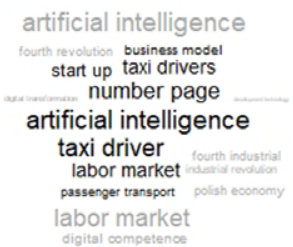

Germany

digital change collective agreement protection business next good work senvice market
artificial intelligence german company data protection digital transformation
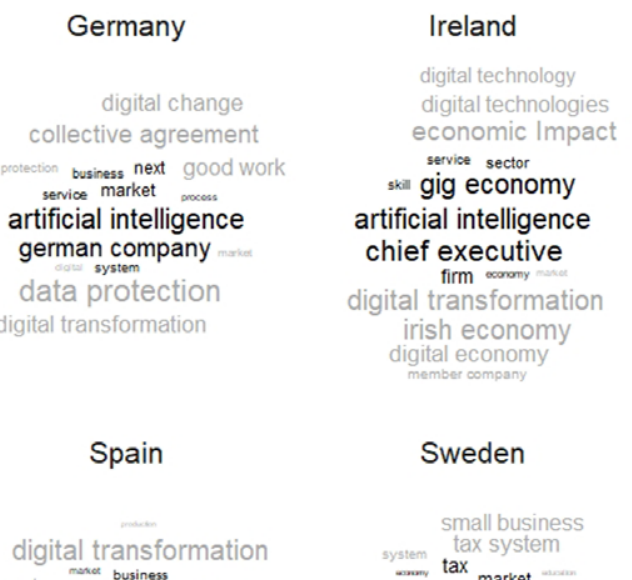
system labor market artificial intelligence digital transformation system podscion
syomen
manogement digital

Spain

\section{Sweden

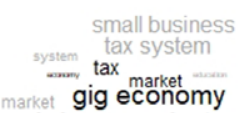 \\ labor market \\ artificial intelligence \\ labor market}

Italy

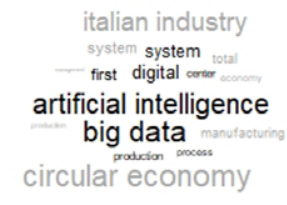

United Kingdom

digital technology good work digital skill trade union labour market artificial intelligence minimum wage gig economy labour market technological change small business

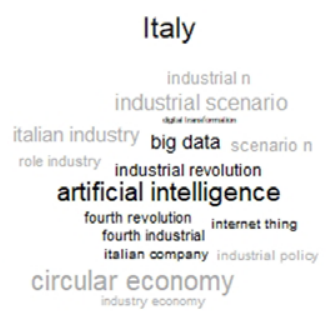

United Kingdom

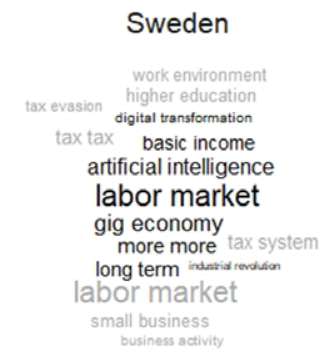

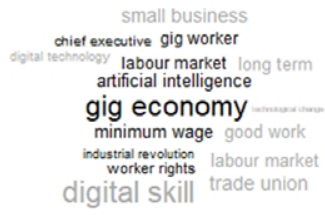

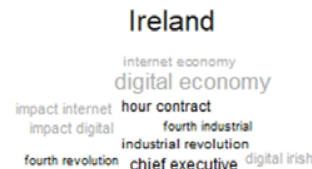

gig economy artificial intelligence labour market
job risk

internet digital irish economy

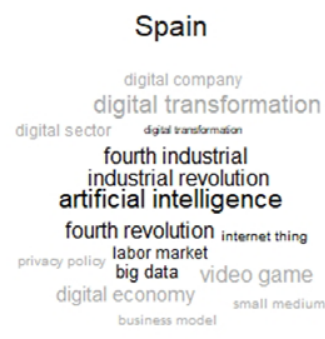

Figure 2. Keywords across countries, with most important keywords for the communicative (black) and coordinative (grey) discourses. Subfigure a depicts the words or phrases with the highest RAKE score across countries. Subfigure b depicts bigrams that occurred most often within a skipgram of size 3 . Subfigure $c$ depicts the bigrams that occurred most often within a sentence across countries.

(or aggregation of topics). It depicts the conditional expectation of a bundled set of topics or 'frame package' to occur in a document given that this document is from a given country. It thus helps us answer the question of which topics are important in some countries relative to others.

So far, we have encountered Sweden as a country with a proactive discourse on digitalization. But while some aspects of digitalization play into Sweden's hands, others challenge the core pillars of its social model. On the one hand, the country's corporatist institutions and 'ideology of social partnership' give it an ability 'to live with change' instead of resisting it (Katzenstein, 1985, pp. 32, 211; Ornston, 2012). This 'asymmetric embrace of markets' (Pontusson, 2011, p. 107) - a perfect 
(c)

France

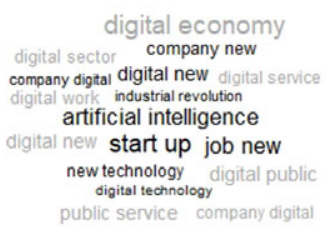

Poland

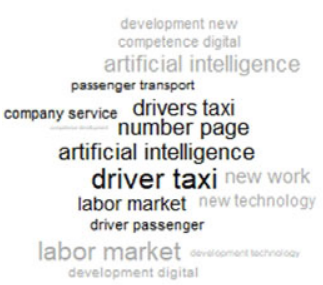

Germany

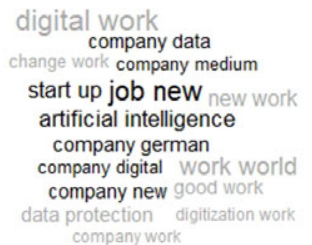

company work

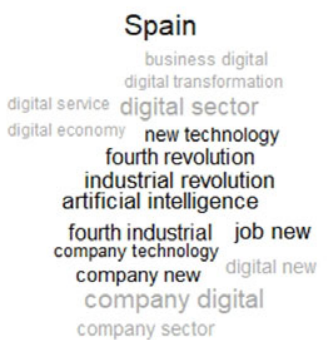

Ireland

business digtal digital technology
digital internet
gig worker
job new job worker
automation job
economy gig
artificial intelligence
economy worker
job risk internet related
gital related digital economy

Sweden

environment work

system tax

approval tax business new

job new

labonmarket

new technology

economy gig company service

basic income

labor market
Italy

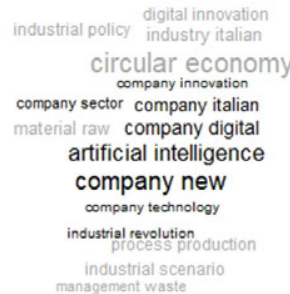

United Kingdom

business small
digital government
digital skill
company worker company worker rights worker automation job economy gis

economy gig gig worker self worker artificial intelligenoe job new work worker business digital digital technology new technology

Figure 2. (Continued)
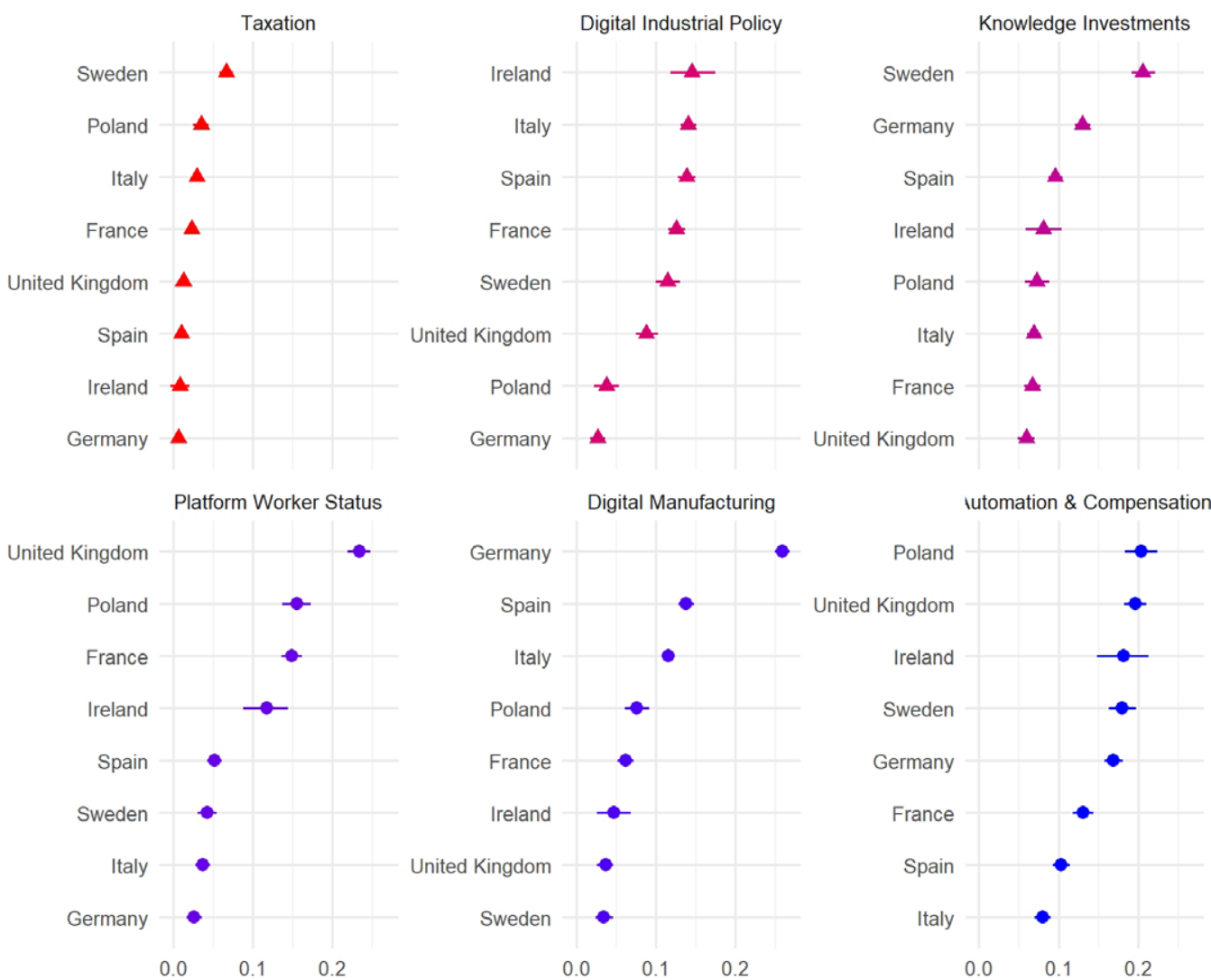

Figure 3. Estimated effect of country variable on the prevalence of topic clusters. Color gradients indicate the ratio of the estimated effect of the discourse type variable, with red colors representing a higher conditional expectation to find the respective topic packages in coordinative (as opposed to communicative) discourses, and blue colors representing the opposite. Triangles indicate that the effect of the coordinate discourse was stronger than the effect of the communicative discourse, i.e. that the ratio of the two was greater than 1. 
example of ideational path dependency (Cox, 2004) - credibly ensures flexible-yet-inclusive adjustments. This stabilizes coalitions for forward-looking adjustments, which, as we have seen, manifests itself in a remarkably positive discourse on digitalization. On the other hand, platform companies like Uber challenge the country's tax-based welfare state and collective bargaining tradition by systematically avoiding taxes and labor market regulations.

This brings actors to the scene that want to defend the Swedish social model and therefore put the issue of taxation on top of the agenda. In fact, tax evasion in the gig economy is a far more important topic in Sweden than in any other country, and mainly so but not exclusively among social partners. Qualitatively, we see this mirrored in the fact that the 'prime concern' of Unionen, Sweden's biggest trade union, is not the employment status of gig workers but that labor platforms follow Swedish taxation rules and collective agreements (Söderqvist, 2017; Thelen, 2018). In what is strong evidence for ideational path dependence, Unionen has developed a 'Nordic approach to regulating labour platforms' that wants to make 'collective agreements easier to integrate and more compatible with the platform firms' software, in essence developing digitalized versions of existing collective agreements' (Söderqvist, 2018, p. 301). In short, rather than banning digital business models, Unionen wants to make it easier for digital platforms 'to be good platforms' (Söderqvist, 2017). Thus, despite the challenges it poses, even Swedish unions see digitalization more as an opportunity - as something that requires a particular response but can ultimately strengthen the Swedish model as long as one is 'proactive in the implementation of the new technology' (Wallin, 2017). ${ }^{8}$

In Germany, the newest wave of digitalization has brought 'deep and transformational changes' (Diessner, Durazzi and Hope, 2020, p. 10) to the country's dominant manufacturing sector, which has sparked an intense debate about its future. This debate, however, was and is not about abandoning manufacturing but about defending it through focusing on the 'digital transformation of products and production within the traditional industrial core' (Thelen, 2019, p. 295). We see this discursive shift reflected in the centrality of digital manufacturing in the German discourse, which comprises topics such as Industry 4.0, smart factories, or cloud computing. What explains this 'ongoing active adaption' (Thelen, 2019, p. 302) to more knowledge-intensive types of manufacturing is the sectorial organization of German producer groups and the dominance of its manufacturing sector therein, which put digital manufacturing high on the agenda, pushed by higher investments in education and R\&D to support this adaption (Thelen, 2019, pp. 300-304).

It is striking to see that across social groups, the challenges posed by digitalization have not been met with protective defensiveness but with a rather proactive willingness to meet them head-on. Central political actors have used their discursive agency to frame digitalization not as something that should be cushioned by compensatory policies but as something that can and should be actively shaped. The SPD-led labor ministry, for example, started a big debate on the future of 'good work' with its influential white paper 'Work 4.0', which served as a discursive focal point. Rather than being overtaken by events, the ministry actively initiated a debate on what 'good work' could look like in the digital age. Moreover, it systematically involved social partners in coming up with answers. This helped shift the debate into issues that social partners could live with or find common ground on, such as flexible working time, training, or data protection. We see this reflected in the keywords on data protection, work time, and further training as well as in the importance of the skills and education frame package. ${ }^{9}$

\footnotetext{
${ }^{8}$ This positive, proactive attitude is echoed in Sweden's corporatist Scandinavian neighbors. In Norway, both unions and employers view automation as fundamental to maintaining the country's labor market and welfare model (Lloyd and Payne 2019 , p. 217) while the Danish union 3F was one of the first to sign a collective agreement with the cleaning service digital platform Hilfr.

${ }^{9} \mathrm{We}$ also reflected this in a topic that is specifically on work councils, collective agreements, data protection, and flexible working hours.
} 
Contrary to their conservative reputation, German unions, too, have 'opted to go on the offensive and adopt a strategy aimed at securing active participation in shaping change, as opposed to rejecting it and then fighting over the consequences' (Haipeter, 2020, p. 242). They have also concentrated on the above-mentioned issues. This allowed them to have a say in shaping digitalization rather than just slowing it down or compensating its losers. They have chiefly done so through work councils and workplace-level agreements, which is quite remarkable given that work councils were not always so proactive about technological change (Haipeter, 2020, p. 247). Germany's corporatist institutions thus channel the German debate in ways that are related to, but cannot be derived from, the particular challenges the country's manufacturing-heavy and export-oriented growth model faces. At the same time, political actors use the corporatist institutional environment to push issues onto the agenda that allow them to have a say in how digital technologies are used, while often doing so in ways that break with institutional path dependencies.

Institutions also shape the terms on which digitalization is discussed in the UK, where there is a widespread perception - further bolstered by combative unions - that digital platforms threaten to put an additional strain on already highly flexible labor markets. We can see this in the many references to gig work, self-employment, zero-hour contracts, or minimum wages. We also see it in the importance of topics about the legal and economic status of platform workers, which, nota bene, is particularly prevalent in communicative discourses. In a climate dominated by fears of a further erosion of worker's rights and the unequal effects of automation on the labor market, even the conservative government had to concede that certain minimum standards needed to be upheld. But, it also emphasized the importance of defending 'the UK's position as one of the best places in the world to do business' (UK Government, 2018b) by continuing the business-friendly tradition of the 'British way'. This has led to a fairly conflictual discourse in which concerns over the regulation of labor platforms (e.g. over the regulation of Uber in London) are layered on top of a wider conflict over the nature and merits of this 'British way'.

Tellingly, topics that are about the threat of automation - either as destroying jobs or increasing inequality - are by far the most prominent in the UK and Ireland. At the same time, topics that are about investments in knowledge-based capital, mainly skills but also universities, research, and digital infrastructures, are much less important. These topics figure more prominently in corporatist Sweden and Germany, and they are overwhelmingly an issue in coordinative discourses. In Germany, in addition to the unions' efforts to put further training center stage, education has been a central concern for the ministry for labor and employment. In fact, the ministry has even toyed with rebranding itself as the ministry for labor and qualification and introducing a right to lifelong learning (interviewee DE-GOV1). In Sweden, Unionen sees digitalization as an important opportunity to mobilize people around the issue of skill formation: 'For a trade union movement that has spent decades trying to convince legislators to invest in lifelong learning, the challenge of digitalization has finally pushed the issue higher up the agenda' (Söderqvist, 2018, p. 298). Such supply side investments also found 'ready allies' (Thelen, 2019, p. 305) among Sweden's most influential business groups (cf. Ornston, 2012).

This underscores the point that corporatist institutions create more future-oriented discourses by allowing actors to collaboratively focus on positive-sum responses to digitalization while mitigating fears of automation (Hicks and Kenworthy, 1998). In the UK and Ireland, such corporatist institutions are much weaker. Especially in Ireland, but also in the UK, there is a debate about digital industrial policy, that is, government measures to support the competitiveness of domestic companies in the digital age. But this debate is precisely not about collaborative investments in knowledge-based capital but about how the government can support domestic businesses through venture funds, taxation, or other developmental tools (for Ireland, see Brazys and Regan, 2017). Overall, we thus find a rather polarized discourse, where governmental actors try to defend the status quo - shoring up the underlying coalition by making smaller concessions - while other actors use digitalization to expose broader problems and push for broader changes, trying to build new coalitions with a potentially responsive public. 
Unsurprisingly, public initiatives are a major topic in France as well, where the state traditionally plays an important role in steering economic transformations (cf. Trumbull, 2004). The national plan on Artificial Intelligence by the Hollande administration is one example of this, Macron's presidency's ambition to transform France into a 'start-up nation' another. Relatedly, France has an intense debate on gig work. The 2016 Loi Travail introduced specific legislation aimed at protecting platform workers. There is, however, also a lot of conflict over what the gig economy is. The very term 'collaborative economy', which is mainly used by the government, is itself contested as it one-sidedly highlights the positive dimension of gig work. This linguistic difference mirrors broader conflicts over digitalization. Unions, platform activists, and the National Digital Council, for example, have criticized the Loi Travail for relying on the social responsibility of digital platforms thereby ruling out labor law solutions (interviewees FR-EXP2/TU1, FR-GOV1, FR-PA1). We see this conflict reflected in the intense debates about the status of platform workers. Thus, not unlike in the UK, the government's ambition to make France a model digital nation clashes with broader concerns about the distributional inequities of the digital economy (interviewee FR-EXP1).

The discourse in Poland is even more contentious, due to highly combative struggles between Uber and taxi groups, which have come to dominate the country's debate on gig work. Different actors - even within the government - hold widely different views on Uber, with some viewing it as an innovative company and arguing for liberalization while others depicting it as a lawbreaker and questioning not only its legality but also its legitimacy (Serafin, 2019). Due to the lack of a cohesive strategy by social partners, and unions, in particular, these conflicts have often taken a Luddite turn culminating in physical attacks on Uber cars and drivers. The other big issue is the impact of artificial intelligence - the by far most important keyword - on the Polish economy. On the one hand, Poland is a potential digital challenger with a relatively large ICT talent pool, relatively high-quality digital infrastructure, and relatively mild legacy of technology lock-ins (McKinsey, 2018). On the other hand, Poland strongly relies on sectors at risk of being further automated, from resource extraction to transport, to ancillary industries (Skóra, 2018). Despite a number of initiatives to speed up the adoption of new technologies, there is no inclusive plan for how to respond to digitalization, with unions focusing on more tangible bread-and-butter issues (Skóra, 2018, p. 465) and many employers not knowing how to incorporate digital technologies into their business model or production processes (Prokop, 2018). As we have seen, this institutional inability to pull together manifests itself in a much more negative coordinative discourse among social partners, and in the prevalence of threatening and contentious keywords and topics.

Similar to Poland, the Spanish discourse is also one of the ambivalences about the effects of the digital transformation, which is seen as both a threat to a country long plagued by economic difficulties and inequalities and as an 'opportunity for change' (Accenture and Mobile World Capital Barcelona, 2017, p. 7). Importantly, however, both the Spanish government and social partners have taken on a more active role in trying to make sure that the latter view becomes reality. Quantitatively, this is reflected in the important role that topics around government support for digitalization play in the Spanish discourse. Qualitatively, it shows itself in a plethora of initiatives such as the Digital Agenda for Spain (2013), the Agenda for Strengthening the Industrial Sector in Spain (2014), the Connected Industry 4.0 Initiative (2015), and the National AI Strategy (2019). Employers have been supportive of such policy initiatives while stressing the need for enhanced labor market flexibility to harness the potential of digitalization, as well as identifying skill shortages as the major obstacle to a successful digital transformation (Confederación Española de Organizaciones Empresariales, 2018). Conversely, unions explicitly recognize the potential benefits of digital technologies but warn against their implications for an already strongly segmented labor market (Comisiones Obreras de Industria, 2016).

While governmental initiatives point to a generally positive but somewhat unilateral discourse, Spanish unions, in particular, have also pushed for more social dialogue around digitalization (interviewee ESP_EXP1). For example, the Connected Industry 4.0 resulted from a state-led open 
consultation process in which unions took part actively while also criticizing it as too 'soft' and not going far enough. Moreover, COO and UGT - the industrial union federations - and the Alliance for the Competitiveness of the Spanish Industry signed the Declaration of Social Partners in 2016, urging the development of a state pact for the industry. Likewise, social partners have promoted the 'Manifesto for the Leadership of Digital Transformation in the Spanish Economy through Talent Development', containing proposals on training and education to succeed in the digital transformation. These deliberate attempts to seek social partner collaboration and government support indicate a push to move the discourse from a more unilateral to a proactive discourse.

Similar to the Spanish discourse, the Italian discourse focuses a lot on the various ways in which Italian companies can compete or be more competitive in a global digital economy. The 2016 'Calenda Plan' on Industry 4.0, which foresaw significant financial incentives for firms that decided to invest in digital technologies, is one example. And we also see this reflected in the importance of digital industrial policy topics in Italian discourse. Similar to Germany, there is a large debate on whether Italian companies can adapt to the digital transformation of manufacturing. Unlike in Germany; however, there is no systematic social partner dialogue about how this transformation can be shaped in a proactive and inclusive manner, initiatives like the CGIL's Progetto Lavoro 4.0 notwithstanding. Reflecting on this lack of a corporatist tradition, the focus is on how the government can help Italian companies survive digitalization, the Calenda Plan being a prominent example. ${ }^{10}$

\section{Conclusion}

There has been much debate as to how platform work and the spread of advanced digital technologies will change the nature of work. In this paper, we have taken a step back and looked at these debates themselves. We have argued that shaping these debates is an essential part of the coalitional work (Emmenegger, 2021) that goes into maintaining or changing institutions. And have found that discourses on the digital future of work are indeed quite different across countries, both in sentiment and content, as dominant social coalitions attempt to frame digitalization in ways that shore up existing institutional arrangements. After all, how digitalization is construed in discourse shapes which political responses are seen as cognitively plausible and normatively desirable. Different problem definitions create different policy imperatives - things that need to be done in response to digitalization - and therefore narrow or broaden the policy solution space (cf. Hay and Rosamond, 2002). For example, if platform work is viewed primarily as an issue of tax avoidance, what is to be done about it will fundamentally be different than if it is viewed as an issue of worker exploitation (cf. Thelen, 2018).

But digitalization discourses are more than institutional reflexes. Actors can reframe debates in order to challenge or reform existing institutional arrangements. An example of this is when German unions departed from their institutional path and took on a more active role in shaping

\footnotetext{
${ }^{10}$ One thing that our analysis does only partly pick up on, and this is true for both Italy and Spain, is the contested debates on the status of gig workers. We do find that Topic 38, on the collective representation of workers, is most prominent in these countries, but topics on the status of platform workers are not as prominent as in the UK. In both Italy and Spain - especially in the latter case - much regulation came from court rulings. But political actors have actively pushed the issue of platform work on the agenda, which is only partly reflected in our analysis. In Spain, Podemos has presented digital platforms as predatory capitalists that flourish at the expense of 'left-behind' workers (interviewee ESP-EXP1). The current government, formed by the Socialist Party and Unidas Podemos alliance, aims at legislating on the matter and Minister of Labor Yolanda Díaz, has started a dialogue with the riders' collective RidersxDerechos. In Italy, the Five Star Movement has been the most active political formation on gig work regulation (interviewee IT-EXP1). When serving as Minister of Economic Development, Labour and Social Policies, Luigi di Maio called food delivery riders a 'symbol of an abandoned generation left with no protection'. After attempts to regulate platform work via social concertation, in November 2019, the so-called 'Riders decree' classified riders as self-employed who nonetheless have access to protections typical of dependent work.
} 
technological change. They did so by shifting the discourse to issues in which they had a good chance of having a say in, such as data protection or flexible working times.

By taking such a discursive and comparative perspective on digitalization, we have advanced the literature on digitalization in three main ways. First, we have demonstrated empirically that digitalization discourses differ systematically. Mapping such discursive differences helps us better understand how institutions shape the way novel problems are assimilated, but also how actors can use their discursive agency to depart from institutional paths. Second, we have taken up the criticism of paired comparisons (Locke and Thelen, 1995) and given it a discursive-institutionalist spin. We have argued that different responses to digitalization cannot be understood as different responses to the same problem. Rather, we stressed the importance of discursive problem construction, and this discursive work is a key part of the coalitional work that goes into maintaining or changing institutions. It is through such discursive processes that global challenges are translated into a series of local problems, which are what countries subsequently 'respond to'. Third, we have demonstrated how novel methods of quantitative text analysis can be used and combined in a comparative framework to capture the sentiment and content of national discourses. This opens up new avenues for comparative research, be it with the intention to generalize findings across contexts or, conversely, to use comparative findings as a starting point for more detailed case studies of how discursive features translate into concrete policy decisions.

Despite these contributions, our study also suffers from two main shortcomings, which future research should remedy. First, it remains agnostic when and under what conditions actors are able to escape their institutional constraints and move discourses in a new direction. Understanding these conditions requires both individual case studies that inquire into the motivations of such discursive entrepreneurs, and more explanatory analyses of the institutional or discursive determinants of such agency (on this, see Emmenegger, 2021). Second, while our study is a successful proof of concept and therefore broader in its focus, this comes at the price of thinner descriptions and somewhat sweeping explanations of discursive differences and changes. In certain respects, therefore, a more detailed look at, say, the employment status of gig workers or the contestation of delivery platforms would have yielded richer results. These shortcomings notwithstanding, our study has shed new light on old questions about the role of ideas and discourse in comparative political economy and opened up what we see as promising avenues for comparative political research.

Supplementary Material. To view supplementary material for this article, please visit https://doi.org/10.1017/S17557739 2100014X.

\section{References}

Accenture (2020), Bridging the Gap: Ireland's Digital Divide. Available at: https://www.accenture.com/_acnmedia/PDF-128/ Accenture-RO-Bridging-The-Gap.pdf\#zoom $=40$.

Accenture and Mobile World Capital Barcelona (2017), 'Digital Economic Opportunity in Spain: September 2017 How digitalization may boost the Spanish Economy’. Available at: https://www.accenture.com/t00010101t000000z w__/es-es/_acnmedia/pdf-59/accenture-strategy-digital-transformation.pdf

Bell, S. (2012), 'Where Are the Institutions? The Limits of Vivien Schmidt's Constructivism', British Journal of Political Science 42(03): 714-719. doi: 10.1017/S0007123411000469

Benoit, K. (2020), 'Text as data: An Overview', in L. Curini and R.J. Franzese (eds.), The SAGE handbook of research methods in political science and international relations. London: SAGE Publications Ltd.

Benoit, K. and A. Matsuo(2020), spacyr: Wrapper to the 'spaCy' 'NLP' Library (Version 1.2.1). Available at: https://cran. r-project.org/package $=$ spacyr

Benoit, K. et al. (2018), 'quanteda: an R package for the quantitative analysis of textual data', Journal of Open Source Software 3(30): 774. doi: 10.21105/joss.00774

Blei, D.M. (2012), 'Probabilistic topic models', Communications of the ACM 55(4): 77. doi: 10.1145/2133806.2133826

Brazys, S. and A. Regan (2017), 'The Politics of Capitalist Diversity in Europe: explaining Ireland's Divergent Recovery from the Euro Crisis', Perspectives on Politics 15(02): 411-427. doi: 10.1017/S1537592717000093

Brynjolfsson, E. and A. McAfee (2014), The Second Machine Age: Work, Progress, and Prosperity in a Time of Brilliant Technologies. New York, NY: Norton. 
Capoccia, G. (2016), 'When Do Institutions "Bite"? Historical Institutionalism and the Politics of Institutional Change', Comparative Political Studies 49(8): 1095-1127. doi: 10.1177/0010414015626449

Comisiones Obreras de Industria (2016), La digitalización de la industria. Available at: https://industria.ccoo.es/ 76ad8479cd94fdf84192c5843d7e8c26000060.pdf

Confederación Española de Organizaciones Empresariales (2018), Plan Digital 2025. La digitalización de la sociedad española. Available at: https://contenidos.ceoe.es/CEOE/var/pool/pdf/publications_docs-file-496-plan-digital-2025-ladigitalizacion-de-la-sociedad-espanolav2.pdf

Cox, R. (2004), 'The Path-dependency of an Idea: why Scandinavian Welfare States Remain Distinct', Social Policy \& Administration 38(2): 204-219. doi: 10.1111/j.1467-9515.2004.00386.x

de Stefano, V. (2016), 'The Rise of the "Just-in-time Workforce": On-Demand Work, Crowd Work and Labour Protection in the "Gig-Economy"', Comparative Labor Law \& Policy Journal 37: 471-503.

Diessner, S., N. Durazzi and D. Hope (2020), 'Liberalization and Skill-Biased Technological Change in the Knowledge Economy: The Critical Case of German Manufacturing', Max Weber Programme Working Paper.

Edmondson, M. (2020), googleLanguageR: Call Google's 'Natural Language' API, 'Cloud Translation' API, 'Cloud Speech' API and 'Cloud Text-to-Speech' API (Version 0.3.0). Available at: https://cran.r-project.org/package=googleLanguageR

Emmenegger, P. (2021), 'Agency in historical institutionalism coalitional work in the creation, maintenance, and change of institutions', Theory and Society. doi: 10.1007/s11186-021-09433-5

Entman, R.M. (1993), 'Framing: toward Clarification of a Fractured Paradigm', Journal of Communication 43(4): 51-58. doi: 10.1111/j.1460-2466.1993.tb01304.x

Frey, C.B. (2019), The technology trap: Capital, labor, and power in the age of automation.

Goodman, P.S. (2017), The Robots Are Coming, and Sweden Is Fine. Available at: https://www.nytimes.com/2017/12/27/ business/the-robots-are-coming-and-sweden-is-fine.html (Accessed: 31 January 2020).

Grimmer, J. and B.M. Stewart (2013), 'Text as Data: the Promise and Pitfalls of Automatic Content Analysis Methods for Political Texts', Political Analysis 21(03): 267-297. doi: 10.1093/pan/mps028

Haipeter, T. (2020), 'Digitalisation, unions and participation: the German case of 'industry 4.0", Industrial Relations Journal 51(3): 242-260. doi: 10.1111/irj.12291

Hall, P.A. (2016), 'Politics as a Process Structured in Space and Time', in K.-O. Fioretos, T.G. Falleti and A.D. Sheingate (eds.), The Oxford Handbook of Historical Institutionalism, Oxford: Oxford University Press, pp. 31-50.

Hall, P.A. and K. Thelen (2009), 'Institutional Change in Varieties of Capitalism', Socio-Economic Review 7(1): 7-34. doi: 10. 1093/ser/mwn020

Hay, C. and B. Rosamond (2002), 'Globalization, European integration and the discursive construction of economic imperatives', Journal of European Public Policy 9(2): 147-167. doi: 10.1080/13501760110120192

Hicks, A. and L. Kenworthy (1998), 'Cooperation and Political Economic Performance in Affluent Democratic Capitalism', American Journal of Sociology 103(6): 1631-1672. doi: 10.1086/231403

Katzenstein, P.J. (1985), Small States in World Markets: Industrial Policy in Europe, Ithaca, N.Y: Cornell University Press. Available at: http://search.ebscohost.com/login.aspx?direct $=$ true\&scope $=$ site $\& \mathrm{db}=$ nlebk\&db $=$ nlabk \&AN=972827

Kjær, P. and O.K. Pedersen (2001), 'Translating Liberalization: Neoliberalism in the Danish Negotiated Economy', in J.L. Campbell, and O.K. Pedersen, (eds.), The Rise of Neoliberalism and Institutional Analysis, Princeton: Princeton University Press, pp. 219-248.

Lloyd, C. and J. Payne (2019), 'Rethinking country effects: robotics, AI and work futures in Norway and the UK', New Technology, Work and Employment 34(3): 208-225. doi: 10.1111/ntwe.12149

Locke, R.M. and K. Thelen (1995), 'Apples and Oranges Revisited: contextualized Comparisons and the Study of Comparative Labor Politics', Politics \& Society 23(3): 337-367.

McKinsey (2018), The rise of Digital Challengers: How digitization can become the next growth engine for Central and Eastern Europe: Perspective on Poland. Available at: https://digitalchallengers.mckinsey.com/files/Rise_of_Digital_Challengers_ Perspective_Poland.pdf

Neufeind, M., J. O’Reilly and F. Ranft (eds.) (2018), Work in the Digital Age: Challenges of the Fourth Industrial Revolution, London: Rowman \& Littlefield International.

Nicholls, T. and P.D. Culpepper (2020), 'Computational Identification of Media Frames: strengths, Weaknesses, and Opportunities', Political Communication, 1-23. doi: 10.1080/10584609.2020.1812777

Ornston, D. (2012), When Small States Make Big Leaps: Institutional Innovation and High-Tech Competition in Western Europe, Ithaca: Cornell University Press.

Pierson, P. (2000), 'Increasing Returns, Path Dependence, and the Study of Politics', American Political Science Review 94(02): 251-267. doi: 10.2307/2586011

Pontusson, J. (2011), 'Once Again a Model: Nordic Social Democracy in a Globalized World', in J.E. Cronin, G. Ross and J. Shoch (eds.), What's Left of the Left: Democrats and Social Democrats in Challenging Times, Durham: Duke University Press, pp. 89-115.

Prassl, J. (2018), Humans as a Service: The Promise and Perils of Work in the Gig Economy, Oxford: Oxford University Press. 
Prokop, J. (2018), Mentality 4.0. How Poland is (not)embracing the digital revolution - Mentality 4.0. How Poland is (not) embracing the digital revolution, 12 October. Available at: https://www.eecpoland.eu/2018/en/news/mentality-4-0-howpoland-is-not-embracing-the-digital-revolution,334665.html (Accessed: 12 October 2020).

Proksch, S.-O. et al. (2019), 'Multilingual Sentiment Analysis: A New Approach to Measuring Conflict in Legislative Speeches', Legislative Studies Quarterly 44(1): 97-131. doi: 10.1111/lsq.12218

Roberts, M.E., B.M. Stewart and D. Tingley (2018), 'stm: R Package for Structural Topic Models', Journal of Statistical Software 10(2): 1-40.

Roberts, Y. (2018), 'The tiny union beating the gig economy giants', 2018. Available at: https://www.theguardian.com/politics/ 2018/jul/01/union-beating-gig-economy-giants-iwgb-zero-hours-workers

Schmidt, V.A. (2008), 'Discursive Institutionalism: the Explanatory Power of Ideas and Discourse', Annual Review of Political Science 11(1): 303-326. doi: 10.1146/annurev.polisci.11.060606.135342

Schmidt, V.A. (2010), 'Taking Ideas and Discourse Seriously: explaining Change through Discursive Institutionalism as the Fourth 'New Institutionalism”, European Political Science Review 2(1): 1-25. doi: 10.1017/S175577390999021X

Schwab, K. (2016), The Fourth Industrial Revolution, Geneva: World Economic Forum.

Serafin, M. (2019), 'Contesting the Digital Economy: Struggles Over Uber in Poland', in S. Schiller-Merkens and P.W. Balsiger (eds.), The contested moralities of markets, Bingley: Emerald Publishing, pp. 187-201.

Skóra, M. (2018), 'Poland: Developing a smart digital agenda', in M. Neufeind, , J. O’Reilly and F. Ranft (eds.), Work in the Digital Age: Challenges of the Fourth Industrial Revolution, London: Rowman \& Littlefield International, pp. 461-470.

Söderqvist, F. (2017), How to unite unions, platforms and government through algorithms? Available at: https://www.youtube. com/watch? $\mathrm{v}=$ We3LV-xD9ok

Söderqvist, F. (2018), 'Will history lead the way in the age of robots and platforms?' in M. Neufeind, J. O'Reilly and F. Ranft (eds.), Work in the Digital Age: Challenges of the Fourth Industrial Revolution, London: Rowman \& Littlefield International, pp. 295-304.

Steinmo, S. and K. Thelen (1992), 'Historical institutionalism in comparative politics', in S. Steinmo and K. Thelen (eds.), Structuring politics: Historical institutionalism in comparative analysis, Cambridge: Cambridge University Press, pp. 1-32.

Streeck, W. and K. Thelen (2005), 'Introduction: Institutional Change in Advanced Political Economies', in W. Streeck, and K. Thelen(eds.), Beyond Continuity: Institutional Change in Advanced Political Economies, Oxford: Oxford University Press, pp. 1-39.

Thelen, K. (2018), 'Regulating Uber: Comparative Perspectives on Work and Welfare in the "Gig" Economy', Perspectives on Politics 16(4): 938-953.

Thelen, K. (2019), 'Transitions to the Knowledge Economy in Germany, Sweden, and the Netherlands', Comparative Politics 51(2): 295-315. doi: 10.5129/001041519825256623

Trumbull, G. (2004), Silicon and the State: French innovation policy in the internet age, Washington/D.C: Brookings Institution Press.

UK Government (2018a), Good Work: A response to the Taylor Review of Modern Working Practices. Available at: https:// assets.publishing.service.gov.uk/government/uploads/system/uploads/attachment_data/file/679767/180206_BEIS_Good_ Work_Report_Accessible_A4_.pdf

UK Government (2018b), Millions to benefit from enhanced rights as government responds to Taylor review of modern working practices. Available at: https://www.gov.uk/government/news/millions-to-benefit-from-enhanced-rights-as-governmentresponds-to-taylor-review-of-modern-working-practices

Vries, E. de, M. Schoonvelde and G. Schumacher (2018), 'No Longer Lost in Translation: evidence that Google Translate Works for Comparative Bag-of-Words Text Applications', Political Analysis 5: 1-14. doi: 10.1017/pan.2018.26

Wallin, G. (2017), A Nordic model for fair platform economies. Available at: www.nordiclabourjournal.org/i-fokus/in-focus2017/sharing-economy-2017/article.2017-05-22.1940247186

Whitley, R. (2007), 'Varieties of institutionalism and their problems: some comments on John Campbell's Institutional Change and Globalization', Socio-Economic Review 5(3): 548-556. doi: 10.1093/ser/mwm001

Wickham, H. et al. (2019), 'Welcome to the Tidyverse', Journal of Open Source Software 4(43): 1686. doi: 10.21105/joss.01686

Wijffels, J. (2019), udpipe: Tokenization, Parts of Speech Tagging, Lemmatization (Version 0.8.3.). Available at: https://cran. r-project.org/package $=$ udpipe

Wueest, B. (2013), 'Varieties of capitalist debates: how institutions shape public conflicts on economic liberalization in the United Kingdom, Germany and France', Comparative European Politics 11(6): 752-772. doi: 10.1057/cep.2012.30

Young, L. and S. Soroka (2012), 'Affective News: the Automated Coding of Sentiment in Political Texts', Political Communication 29(2): 205-231. doi: 10.1080/10584609.2012.671234

Cite this article: Marenco M and Seidl T (2021). The discursive construction of digitalization: a comparative analysis of national discourses on the digital future of work. European Political Science Review 13, 391-409. https://doi.org/10.1017/ S175577392100014X 